Bangladesh J. Plant Taxon. 20(1): 9-18, 2013 (June)

(C) 2013 Bangladesh Association of Plant Taxonomists

\title{
NUTLET MORPHOLOGY AND ITS TAXONOMIC SIGNIFICANCE IN THE GENUS MENTHA L. (LAMIACEAE) FROM TURKEY
}

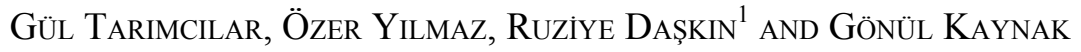 \\ Department of Biology, Faculty of Arts and Science, Uludag University, \\ 16059 Görükle Bursa, Turkey
}

Keywords: Nutlet morphology; Taxonomy; SEM; Mentha; Lamiaceae; Turkey.

\begin{abstract}
The nutlet morphology of 11 taxa of Mentha L. (M. pulegium, M. aquatica, M. × piperita, M. х dumetorum, $M$. spicata subsp. spicata, $M$. spicata subsp. tomentosa, $M . \times$ villoso-nervata, M. longifolia subsp. longifolia, M. longifolia subsp. typhoides, $M . \times$ rotundifolia and $M$. suaveolens) distributed throughout Turkey was investigated by scanning electron microscopy (SEM). The shape of all studied nutlets was broadly oblong or ovoid. Nutlet size ranged from 0.54 to $0.97 \mathrm{~mm}$ in length and from 0.37 to 0.66 $\mathrm{mm}$ in width. The smallest and biggest nutlets were found in $M . \times$ villoso-nervata and $M$. aquatica, respectively. The Mentha taxa studied can be divided into three groups, based on nut sculpturing type such as distinctly bireticulate, inconspicuously bireticulate and reticulate. This study has shown that some nutlet morphological characteristics can be utilised as additional diagnostic characteristics in delimitations of Mentha at the species and infraspecific levels.
\end{abstract}

\section{Introduction}

Mentha L., one of the most important genera of the family Lamiaceae, has worldwide distribution and it consists of perennial aromatic herbs. Some Mentha species, such as $M$. pulegium L., M. longifolia (L.) Huds., M. spicata L., M. × piperita L. and M. × villoso-nervata Opiz, are traditionally used in folk medicine (Baytop, 1999). Mint oil and their constituents obtained from different species of Mentha are also used in perfumery, cosmetics and food industries (Kokkini, 1994).

Mentha is a taxonomically difficult genus because of extensive hybridization, vegetative propagation, polyploidisation and cultivation (Harley, 1972; Harley and Brighton, 1977; Tucker et al., 1980). The genus comprises 18 species and 11 hybrids placed into four sections, namely Pulegium, Tubulosae, Eriodontes and Mentha according to the latest taxonomic treatment (Tucker and Naczi, 2007). Harley (1982) recognized 11 Mentha taxa belonging to two sections (Pulegium and Mentha) from Turkey and then two hybrids have been added to Flora of Turkey (Tarimcilar and Kaynak, 1997a, b). In this study, the treatment of Harley (1982) has been followed for the nomenlature of Mentha.

There are some studies about monophyly of Mentha and phylogenetic relationships within the genus (Gobert et al., 2002; Bunsawat et al., 2004; Shasany et al., 2005). Saric-Kundelic et al. (2009) investigated the utility of morphological, anatomical and phytochemical characters for the identification of Mentha species, hybrids, varieties and cultivars in Bosnia-Herzegovina and Slovakia. In various genera of family Lamiaceae, the nutlet morphology, anatomy, pericarp structure and their taxonomic significance have been reported by some studies (Husain et al., 1990; Marin et al., 1994; Ryding, 2010). However, accounts on the mericarp morphology of some

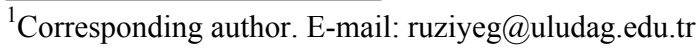


taxa of Mentha examined in this study are rather limited (Duletic-Lausevic and Marin, 1999; Moon et al., 2009). We aim in this study, with the aid of scanning electron microscope (SEM), to provide detailed data on nutlet morphology of 11 Mentha taxa found in Turkey and to determine which characteristics of their nutlets may be used for taxonomic purposes.

\section{Materials and Methods}

Plant materials:

Nutlets of 11 taxa of Mentha collected from different parts of Turkey were investigated. The materials used in this study were composed mainly of herbarium specimens, which were deposited in the herbarium of Uludag University (BULU). The specimens used for SEM micrographs were presented in Table 1.

Nutlet size and SEM analyses:

For nutlet length and width, 50 nutlets were measured per taxon. However, at least 10 nutlets were measured for hybrids. In order to ensure that the nutlets were of normal size and maturity, they were examined using a stereomicroscope. For SEM, nutlets of taxa were transferred directly to a double-sided tape-affixed stub and were coated with gold-palladium, using a BAL-TEC SCD 005 sputter. The micrographs were obtained from a CARL ZEISS Evo 40 SEM using a voltage of $20 \mathrm{kV}$ at the Microscopy Laboratory of Science and Art Faculty of Uludag University. The micrographs were used to describe surface sculpturing type of nutlets. The terminology for nutlet shape and surface sculpturing mainly follows that of Barthlott (1981) and Stearn (1983).

Table 1. List of taxa used for SEM micrograph (GT- Gül Tarımclar).

\begin{tabular}{|c|c|c|c|}
\hline No. & Taxon & Collection data & Vouchers \\
\hline 1 & M. aquatica L. & A2 Bursa: Fadilli village, 9 m, 3.9.2004 & GT 30514 \\
\hline 2 & M. $\times$ dumetorum Schult. & A1Kirklareli: Babaeski, 60 m, 23.8.2003 & GT 30448 \\
\hline 3 & M. pulegium L. & A2 Istanbul: Cavusbasi, 16.8.2005 & GT 30533 \\
\hline 4 & $\begin{array}{l}\text { M. longifolia (L.) Huds. subsp. } \\
\text { longifolia }\end{array}$ & A2 Bursa: Gemlik, Hayriye village, 10 m, 8.9.2006 & GT 30592 \\
\hline 5 & $\begin{array}{l}\text { M. longifolia (L.) Huds. subsp. } \\
\text { typhoides (Briq.) Harley }\end{array}$ & A2 Istanbul: Sile, 15.8.2005 & GT30530 \\
\hline 6 & M. $\times$ piperita L. & A2 Istanbul: Cavusbasi, Kavaklık, 16.8.2005 & GT 30535 \\
\hline 7 & M. $\times$ rotundifolia $($ L. $)$ Huds. & B1 Balikesir: Bandırma to Erdek, 130 m, 27.8.2004 & GT 30508 \\
\hline 8 & M. spicata L. subsp. spicata & A1 Tekirdag: $1 \mathrm{~km}$ to Hayrabolu, $70 \mathrm{~m}, 23.8 .2003$ & GT 30452 \\
\hline 9 & $\begin{array}{l}\text { M. spicata L. subsp. tomentosa } \\
\text { (Briq.) Harley }\end{array}$ & A2 Bilecik: Pazaryeri, Bahcesultan, 1050 m, 6.9.2006 & GT 30562 \\
\hline 10 & M. suaveolens Ehrth. & A2 Yalova: Sultaniye, $25 \mathrm{~m}, 7.6 .2006$ & GT 30570 \\
\hline 11 & M. × villoso-nervata Opiz. & $\begin{array}{l}\text { B1Canakkale: Saros, Kocacesme village, } \\
35 \mathrm{~m}, 25.8 .2004\end{array}$ & GT 30470 \\
\hline
\end{tabular}

\section{Results and Discussion}

The characteristics of nutlet (i.e. size, colour, presence or absence of trichomes and surface sculpturing) are summarized in Table 2. Micrographs of nutlets belonging to all studied taxa are presented in Figures 1-4. We found that the shape of all studied nutlets was broadly oblong or ovoid and that nutlet colour varied from pale to dark brown. The nutlets of M. pulegium, $M$. aquatica and $M$. dumetorum were pale brown, while those of $M . \times$ piperita, $M . \times$ villoso-nervata 
and $M . \times$ rotundifolia were dark brown. However, the colour of the nutlets in $M$. spicata subsp. spicata, M. spicata subsp. tomentosa, M. longifolia subsp. longifolia, M. longifolia subsp. typhoides and $M$. suaveolens varied from chestnut brown to dark brown. Moreover, short or long trichomes were observed on the surface of nutlets of $M$. aquatica, $M$. × dumetorum, $M$. spicata subsp. tomentosa and $M$. longifolia subsp. longifolia. Nutlet size ranged from 0.54 to $0.97 \mathrm{~mm}$ in length and from 0.37 to $0.66 \mathrm{~mm}$ in width. The smallest nutlet was found in $M . \times$ villoso-nervata and the biggest nutlet was found in M. aquatica (Table 2).
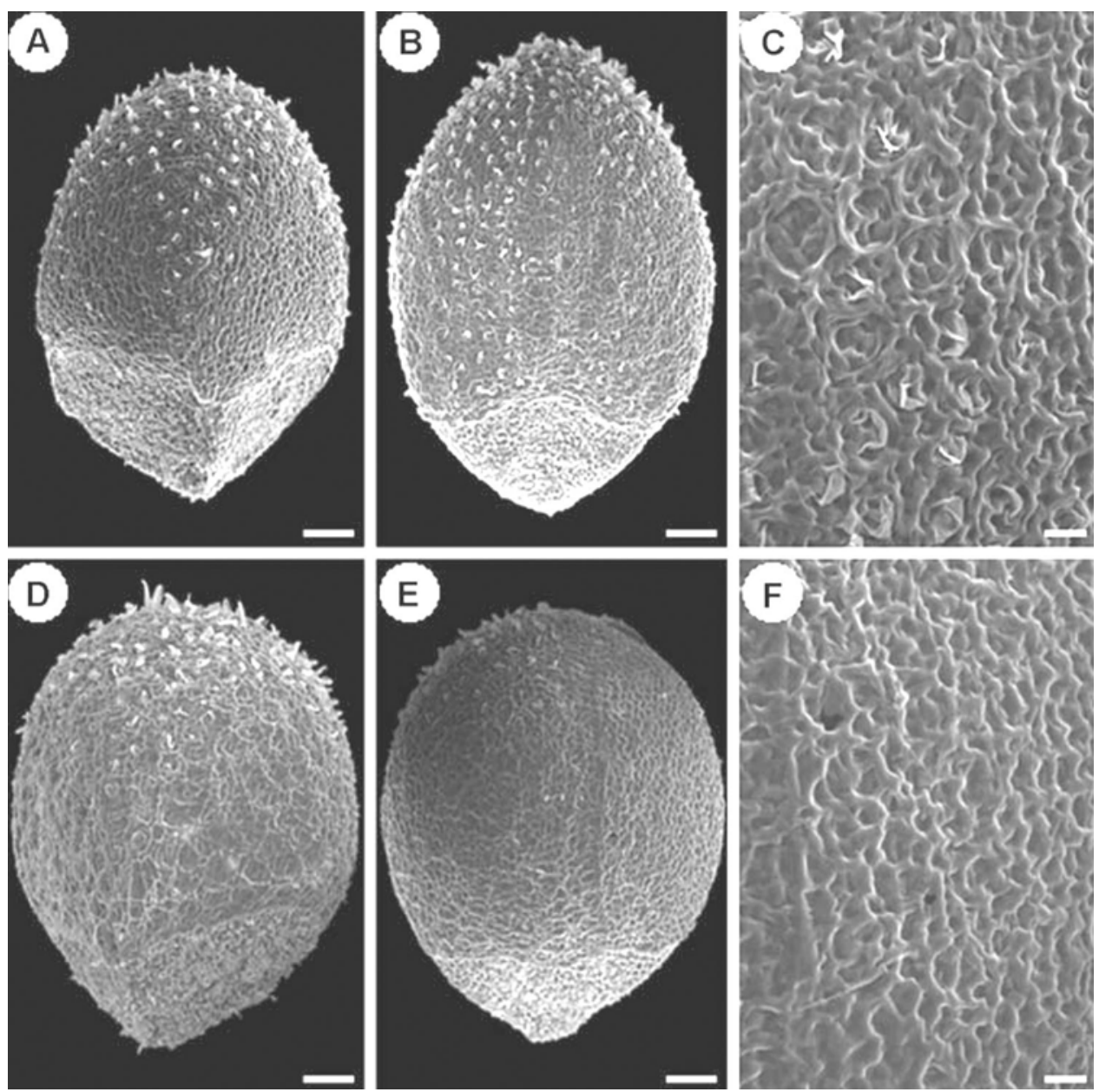

Fig. 1. SEM micrographs of nutlets of Mentha aquatica (A-C); M. $\times$ dumetorum (D-F); Ventral view (A, D); dorsal view (B, E); surface sculpturing (C, F). Scale bars: A, B, D, E = $100 \mu \mathrm{m} ; \mathrm{C}, \mathrm{F}=20 \mu \mathrm{m}$.

Under SEM, three types were observed in the Mentha taxa based on surface sculpturing pattern:

Type I. Distinctly bireticulate: a surface with penta- or hexagonal-shaped small cells, and the walls of these cells are high, irregular and having depressions. This sculpturing pattern was seen in M. aquatica and M. × dumetorum (Fig. 1C, F). 
Table 2. Nutlet characteristics of the studied taxa of Mentha $\mathbf{L}$.

\begin{tabular}{|c|c|c|c|c|c|c|}
\hline \multirow[t]{2}{*}{ Taxon } & \multirow{2}{*}{$\begin{array}{l}\text { Length }(\mathrm{mm}) \\
\text { Mean } \pm \text { SD }\end{array}$} & Width (mm) & \multirow[t]{2}{*}{ Sculpture } & \multirow{2}{*}{$\begin{array}{l}\text { Presence/ } \\
\text { absence of } \\
\text { trichomes }\end{array}$} & \multirow[t]{2}{*}{ Colour } & \multirow[t]{2}{*}{ Figures } \\
\hline & & Mean \pm SD & & & & \\
\hline M. aquatica & $0.9 \pm 0.07$ & $0.6 \pm 0.05$ & TYPE I & short hair & pale brown & Fig. 1A-C \\
\hline M. $\times$ dumetorum & $0.8 \pm 0.15$ & $0.6 \pm 0.06$ & TYPE I & short hair & pale brown & Fig. 1D-F \\
\hline M. pulegium & $0.7 \pm 0.01$ & $0.5 \pm 0.04$ & TYPE II & absent & pale brown & Fig. 2A-C \\
\hline M. $\times$ piperita & $0.7 \pm 0.04$ & $0.5 \pm 0.04$ & TYPE II & absent & dark brown & Fig. 2D-F \\
\hline M. spicata subsp. spicata & $0.8 \pm 0.02$ & $0.6 \pm 0.01$ & TYPE II & absent & $\begin{array}{l}\text { chestnut to } \\
\text { dark brown }\end{array}$ & Fig. 2G-I \\
\hline M. spicata subsp. tomentosa & $0.7 \pm 0.01$ & $0.5 \pm 0.01$ & TYPE III & $\begin{array}{l}\text { scarcely } \\
\text { hair }\end{array}$ & $\begin{array}{l}\text { chestnut to } \\
\text { dark brown }\end{array}$ & Fig. 3A-C \\
\hline $\begin{array}{l}\text { M. longifolia subsp. } \\
\text { longifolia }\end{array}$ & $0.6 \pm 0.06$ & $0.5 \pm 0.07$ & TYPE III & long hair & $\begin{array}{l}\text { chestnut to } \\
\text { dark brown }\end{array}$ & Fig. 3D-F \\
\hline $\begin{array}{l}\text { M. longifolia subsp. } \\
\text { typhoides }\end{array}$ & $0.7 \pm 0.01$ & $0.5 \pm 0.03$ & TYPE III & absent & $\begin{array}{l}\text { chestnut to } \\
\text { dark brown }\end{array}$ & Fig. 3G-I \\
\hline M. $\times$ villoso-nervata & $0.6 \pm 0.02$ & $0.4 \pm 0.03$ & TYPE III & absent & dark brown & Fig. $4 \mathrm{~A}-\mathrm{C}$ \\
\hline M. suaveolens & $0.6 \pm 0.02$ & $0.5 \pm 0.02$ & TYPE III & absent & $\begin{array}{l}\text { chestnut to } \\
\text { dark brown }\end{array}$ & Fig. 4D-F \\
\hline M. $\times$ rotundifolia & $0.6 \pm 0.02$ & $0.4 \pm 0.01$ & TYPE III & absent & dark brown & Fig. 4G-I \\
\hline
\end{tabular}

Type II. Inconspicuously bireticulate: a surface covers inconspicuously penta- or hexagonalshaped small cells, and these cells having various walls. M. pulegium, M. $\times$ piperita and $M$. spicata subsp. spicata exhibited this type of sculpturing. Only in M. pulegium, the nutlets with cells having rigid cell boundary and having star-shaped extensions at their centres (Fig. 2C). The nutlets of M. × piperita and M. spicata subsp. spicata with cells having wrinkled or often unclear walls (Fig. 2F, I).

Type III. Reticulate: a surface with penta- or hexagonal-shaped cells having large lumen and smooth, regular walls and forming a net-like appearance on their surface. The nutlets of M. spicata subsp. tomentosa, M. longifolia subsp. longifolia, M. longifolia subsp. typhoides, $M . \times$ villosonervata, M. suaveolens and M. × rotundifolia exhibited this type (Figs 3C, F, I; 4C, F, I).

When the nutlet characteristics of the investigated Mentha taxa were compared with previous literature (Ball, 1972; Borisova, 1977; Tarimcilar and Kaynak, 2002), our results are more or less similar to their findings. The shape of nutlets examined in this study was broadly oblong or ovoid. Borisova (1977), Harley (1982) and Tarimcilar and Kaynak (2002) have reported that the nutlet shape of the genus Mentha varies from globose to ovoid or obovoid.

Duletic-Lausevic and Marin (1999) found nutlet dimensions $0.7 \times 0.5 \mathrm{~mm}$ in M. pulegium and M. longifolia, $0.8 \times 0.6 \mathrm{~mm}$ in M. aquatica, $0.6 \times 0.4 \mathrm{~mm}$ in $M$. spicata and $M$. $\times$ rotundifolia, and $0.6 \times 0.5 \mathrm{~mm}$ in M. suaveolens. Moon et al. (2009) examined nutlet characteristics (i.e. size, colour, shape and surface sculpturing) of Mentha aquatica, M. longifolia, and M. suaveolens and reported the length and width measurements $(\mathrm{mm})$ as $1 \pm 0.05 \times 0.7 \pm 0.02,0.6 \pm 0.03 \times 0.5 \pm 0.02$ and $0.6 \pm 0.03 \times 0.4 \pm 0.02$, respectively. Nutlet shape of these taxa is widely elliptic, surface sculpturing type is reticulate, and colour varies from yellowish brown to reddish dark brown (Moon et al., 2009).

According to our results, the nutlets of $M$. aquatica, M. $\times$ dumetorum, M. spicata subsp. tomentosa and $M$. longifolia subsp. longifolia have trichomes. The presence or absence of trichomes on nutlet is an important character to discriminate M. longifolia subsp. longifolia and subsp. typhoides which have the similar nutlet size, sculpturing and colour (Table 2). On the other 
hand, Duletic-Lausevic and Marin (1999) stated that the nutlets of M. spicata, M. rotundifolia and $M$. suaveolens lack trichomes and that M. aquatica and M. longifolia exhibit nutlets with or without trichomes.
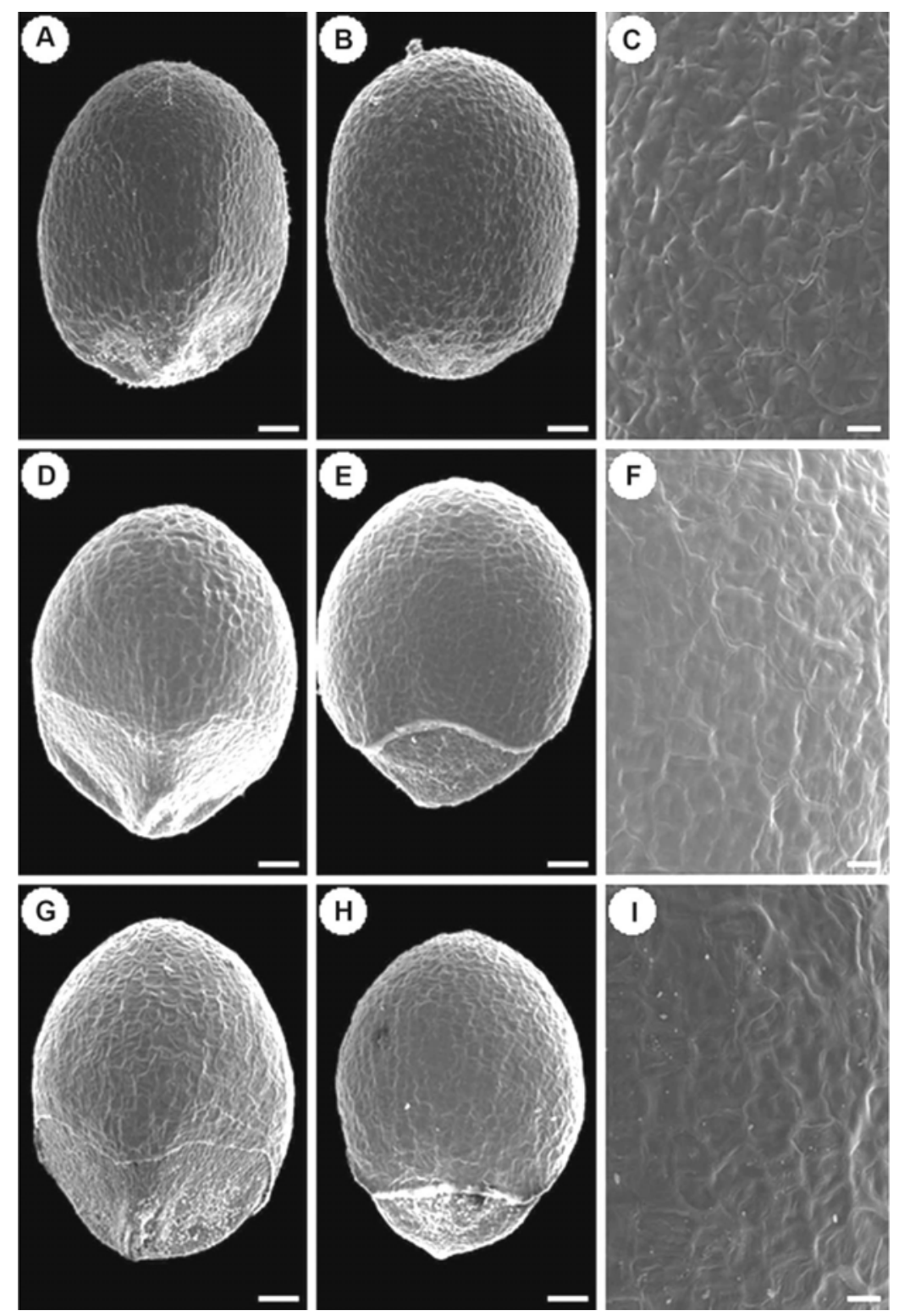

Fig. 2. SEM micrographs of nutlets of M. pulegium (A-C); M. × piperita (D-F); M. spicata subsp. spicata (G-I). Ventral view (A, D, G); dorsal view (B, E, H); surface sculpturing (C, F, I). Scale bars: A, B, D, E, $\mathrm{G}, \mathrm{H}=100 \mu \mathrm{m} ; \mathrm{C}, \mathrm{F}, \mathrm{I}=20 \mu \mathrm{m}$. 

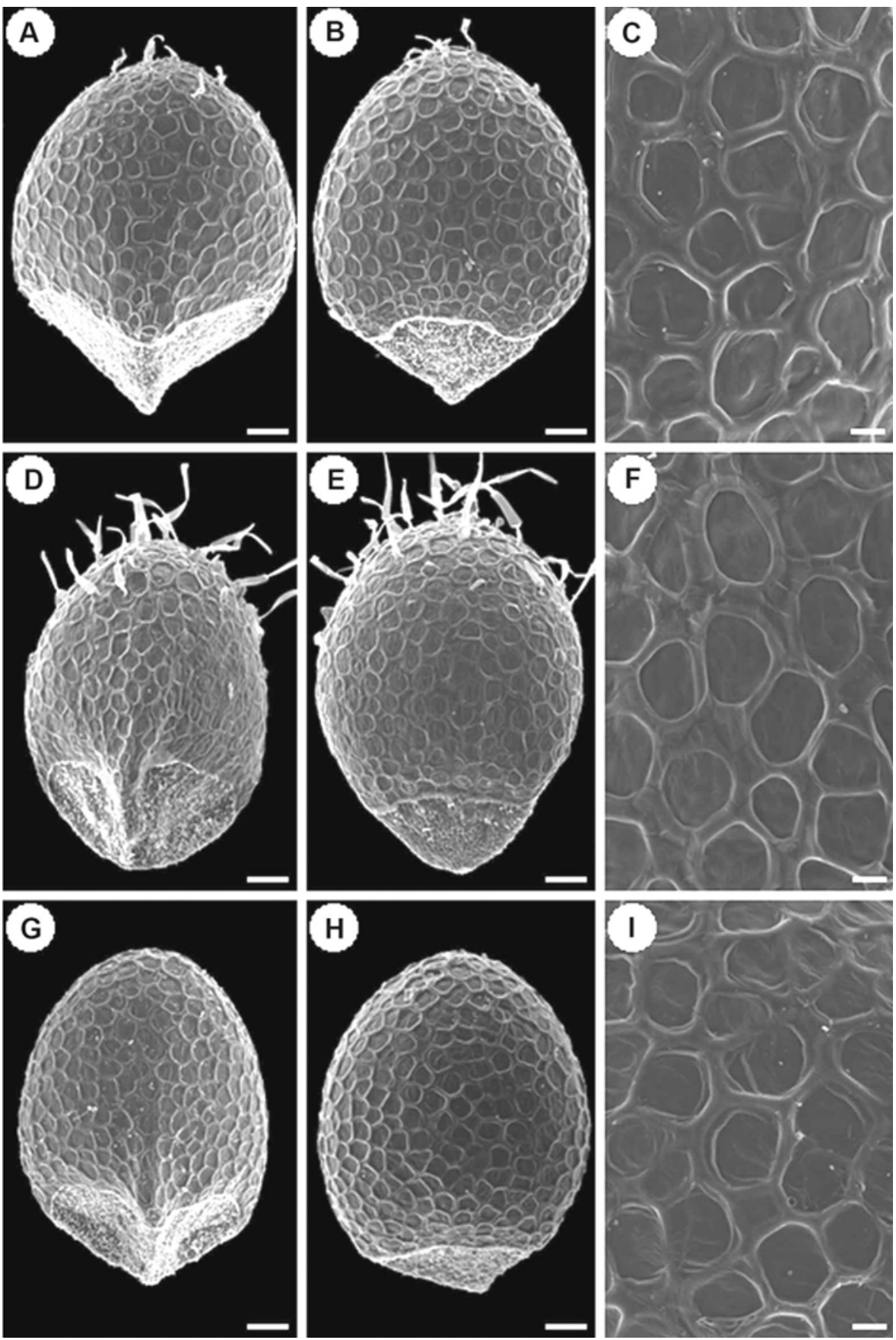

Fig. 3. SEM micrographs of nutlets of M. spicata subsp. tomentosa (A-C); M. longifolia subsp. longifolia (D-F); M. longifolia subsp. typhoides (G-I). Ventral view (A, D, G); dorsal view (B, E, H); surface sculpturing (C, F, I). Scale bars: A, B, D, E, G, H = $100 \mu \mathrm{m}$; C, F, I = $20 \mu \mathrm{m}$. 

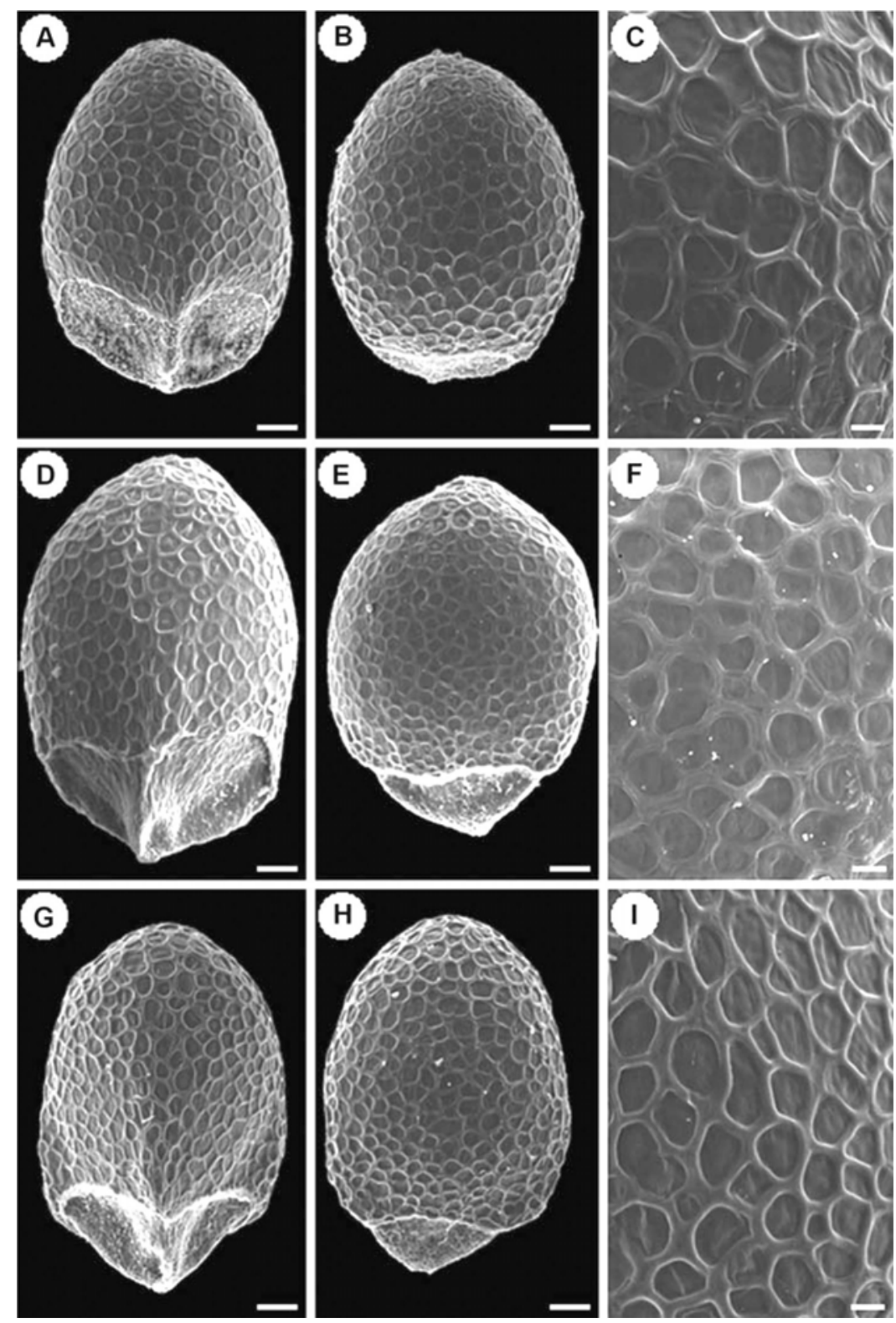

Fig. 4. SEM micrographs of nutlets of $M . \times$ villoso-nervata (A-C); . suaveolens (D-F); $M . \times$ rotundifolia (G-I). Ventral view (A, D, G); dorsal view (B, E, H); surface sculpturing (C, F, I). Scale bars: A, B, D, E, $\mathrm{G}, \mathrm{H}=100 \mu \mathrm{m} ; \mathrm{C}, \mathrm{F}, \mathrm{I}=20 \mu \mathrm{m}$.

Mentha taxa employed in this study can be divided into three informal groups, with regard to nutlet characteristics basically sculpturing patterns. Group I includes M. aquatica, M. × dumetorum (M. aquatica $\times$ M. longifolia) and they are similar to each other both in terms of the morphological features and the nutlet characteristics. However, $M . \times$ dumetorum differs from $M$. aquatica in its more oblong spikes and narrower leaves (Tarimcilar and Kaynak, 1997a, 2002). 
Group II consists of M. pulegium, M. spicata subsp. spicata and M. × piperita (M. aquatica $\times$ M. spicata). Of the studied Mentha taxa, only M. pulegium is located in sect. Pulegium, whereas the others are included in sect. Mentha. Sect. Pulegium is distinguished from sect. Mentha by its bracts similar to leaves, tubular calyx, weakly 2-lipped, with distinctly unequal calyx teeth, hairy within calyx throat, gibbous corolla tube. Sect. Mentha have variable bracts, calyx tubular or campanulate, with more or less equal calyx teeth, glabrous calyx throat and straight corolla tube (Harley, 1982). Moreover, the inflorescence of $M$. × piperita is morphologically similar to $M$. spicata in that it forms a terminal spike, but it differs from $M$. aquatica in its more lanceolate leaves that have shorter petioles (3-9 mm or rarely more).

Group III includes M. spicata subsp. tomentosa, M. longifolia subsp. longifolia, M. longifolia subsp. typhoides, $M . \times$ villoso-nervata, M. suaveolens and $M . \times$ rotundifolia. The nutlet surfaces of this group are covered with penta- or hexagonal-shaped cells that form a particularly net-like appearance. $M$. × villoso-nervata $(M$. spicata $\times M$. longifolia $)$ is morphologically different from the parents in its narrower spikes and smaller leaves and calyx (Tarimcilar and Kaynak, 1997b, 2002). . $\times$ rotundifolia ( $M$. suaveolens $\times M$. longifolia) resembles $M$. suaveolens in its pale green and strongly rugose leaves, but it differs in that its leaves are more oblong and have an acute apex (Harley, 1982; Tarimcilar and Kaynak, 2002).

Hybrids can be distinguished from their parental species in terms of some nutlet features. As seen in Table 2, M. $\times$ dumetorum mainly differs from $M$. aquatica and $M$. longifolia with its smaller and distinctly bireticulate sculpturing nutlet. The nutlets of $M$. × piperita are smaller than those of $M$. spicata subsp. spicata, but they are more similar to $M$. spicata than $M$. aquatica in terms of nutlet characteristics. They are easily distinguishable from $M$. aquatica due to its inconspicously bireticulate, glabrous and dark brown nutlet. $M . \times$ villoso-nervata differs from $M$. longifolia subsp. longifolia and $M$. spicata subsp. spicata by its glabrous, dark brown and reticulate nutlet, respectively. The nutlet characteristics of $M . \times$ rotundifolia and $M$. suaveolens display a great similarity with each other.

A key can be established based on nutlet chacteristics for Turkish Mentha taxa:

1 Nutlet sculpturing bireticulate

- Nutlet sculpturing reticulate

2 Nutlet sculpturing distinctly bireticulate

- Nutlet sculpturing inconspicously bireticulate

3 Nutlets at least $0.83 \mathrm{~mm}$ long

- $\quad$ Nutlets at least $0.65 \mathrm{~mm}$ long

4 Nutlets $0.78-0.82 \mathrm{~mm}$ long M. × dumetorum

- $\quad$ Nutlets shorter than $0.78 \mathrm{~mm}$

M. spicata subsp. spicata

5 Nutlet cells with star-shaped extensions at their centres

- $\quad$ Nutlet cells without star-shaped extensions at their centres

M. pulegium

Nutlets without hair

M. × piperita

- Nutlets with hair

7 Nutlets $0.47-0.53 \mathrm{~mm}$ wide

- Nutlets 0.37-0.43 mm wide

8 Nutlets $0.69-0.71 \mathrm{~mm}$ long

- $\quad$ Nutlets 0.58-0.62 mm long

M. longifolia subsp. typhoides M. suaveolens 
9 Nutlets at least $0.39 \mathrm{~mm}$ wide

- $\quad$ Nutlets at least $0.37 \mathrm{~mm}$ wide

10 Nutlets $0.69-0.71 \mathrm{~mm}$ long

- $\quad$ Nutlets 0.54-0.66 mm long
M. $\times$ rotundifolia

M. $\times$ villoso-nervata

M. spicata subsp. tomentosa

M. longifolia subsp. longifolia

The utility of nutlet characters, i.e. shape, size, presence or absence of hairs, nature of indumentum, surface sculpturing, exocarp cellular morphology and anatomy of the nutlet has been shown at various taxonomic levels in different genera of Lamiaceae (Husain et al., 1990; Marin et al., 1994; Duletic-Lausevic and Marin, 1999; Moon and Hong, 2006). Our findings also showed that the nutlet size, presence/absence of trichomes, surface sculpturing pattern are valuable diagnostic characteristics for separating closely related taxa of Mentha. In conclusion, we can say that nutlet morphological characteristics combined with other morphological characters can be used for delimination of taxa at the species and infraspecific levels in the genus Mentha. Furthermore, this study provides the detailed data on the nutlet features of Turkish Mentha taxa.

\section{Acknowledgements}

We thank Research Foundation of Uludag University (project numbers F-2003/3 and F2005/4) for financial support.

\section{References}

Ball, P.W. 1972. Mentha L. In: Tutin, T.G., Heywood, V.H., Burges, N.A., Moore, D.M., Valentine, D.H., Walters, S. and Webb, B.A. (Eds), Flora Europaea. Vol. 3. Cambridge Univ. Press, Cambridge, pp. 183186.

Barthlott, W. 1981. Epidermal and seed surface characters of plants: systematic applicability and some evolutionary aspects. Nord. J. Bot. 1: 345-355.

Baytop, T. (Ed.). 1999. Türkiye'de Bitkiler ile Tedavi, Nobel Kitabevleri, pp. 302-304.

Borisova, A.G. 1977. Mentha L. In: Shishkin, B.K. (Ed.), Flora of the U.S.S.R. Vol. 21. Translated from Russian Israel Program for Scientific Translations, Jerusalem, pp. 427-449.

Bunsawat, J., Elliott N.E., Hertweck, K.L., Sproles, E. and Alice, L.A. 2004. Phylogenetics of Mentha (Lamiaceae): Evidence from chloroplast DNA sequences. Syst. Bot. 29: 959-964.

Duletic-Lausevic, S. and Marin, P.D. 1999. Pericarp structure and myxocarpy in selected genera of Nepetoideae (Lamiaceae). Nord. J. Bot. 19: 435-446.

Gobert, V., Moja, S., Colson, M. and Taberlet, P. 2002. Hybridization in the section Mentha (Lamiaceae) inferred from AFLP markers. Amer. J. Bot. 89: 2017-2023.

Harley, R.M. 1972. Notes on the genus Mentha L. (Labiatae). Bot. J. Linn. Soc. 65: 250-253.

Harley, R.M. 1982. Mentha L. In: Davis, P.H. (Ed.), Flora of Turkey and the East Aegean Islands. Vol. 7. Edinburgh Univ. Press, Edinburgh, pp. 384-394.

Harley, R.M. and Brighton, C.A. 1977. Chromosome numbers in the genus Mentha L. Bot. J. Linn. Soc. 74: 71-96.

Husain, S.Z., Marin, P.D., Silic, C., Qaiser, M. and Petkovic, B. 1990. A micromorphological study of some representative genera in the tribe Saturejeae (Lamiaceae). Bot. J. Linn. Soc. 103: 59-80.

Kokkini, S. 1994. Herbs of the Labiatae. In: Macrae, R., Robinson, R.K. and Sadler, M.J. (Eds), Encyclopedia of Food Science, Food Technology and Nutrition, Vols. 1-8. Academic Press, London, pp. 2342-2348.

Marin, P.D., Petkovic B.P. and Duletic, S. 1994. Nutlet sculpturing of selected Teucrium species (Lamiaceae): A character of taxonomic significance. Plant Syst. Evol. 192: 199-214.

Moon, H. and Hong, S. 2006. Nutlet morphology and anatomy of the genus Lycopus (Lamiaceae: Mentheae). J. Pl. Res. 119: 633-644. 
Moon, H., Hong, S., Smets, E. and Huysmans, S. 2009. Micromorphology and character evolution of nutlets in tribe Mentheae (Nepetioideae, Lamiaceae). Syst. Bot. 34: 760-776.

Ryding, O. 2010. Pericarp structure and phylogeny of tribe Mentheae (Lamiaceae). Plant Syst. Evol. 285: 165-175.

Saric-Kundelic, B., Fialova, S., Dobes, C., Olzant, S., Tekelova, D., Grancai, D., Reznicek, G. and Saukel, J. 2009. Multivariate numerical taxonomy of Mentha species, hybrids, varieties and cultivars. Sci. Pharm. 77: 851-876.

Shasany, A.K., Darokar, M.P., Dhawan, S., Gupta, A.K., Shukla, A.K., Patra, N.K. and Khanuja, S.P.S. 2005. Use of RAPD and AFLP markers to identify inter- and intrasepecific hybrids of Mentha. J. Heredity 96: 542-549.

Stearn, W. T. (Ed.) 1983. Botanical Latin. 3rd rev., David \& Charles Inc., Vermont.

Tarimcilar, G. and Kaynak, G. 1997a. A new record for the Flora of Turkey. Turk. J. Bot. 21: 247-249.

Tarimcilar, G. and Kaynak, G. 1997b. A new record for the Flora of Turkey. Lagascalia 20: 113-115.

Tarimcilar, G. and Kaynak, G. 2002. A morphological study on Mentha L. (Labiatae) taxa of Black Sea region. Süleyman Demirel Üniv. Fen Bil. Enst. Derg. 5: 194-229.

Tucker, A.O., Harley, R.M. and Fairbrothers, D.E. 1980. The Linnean Types of Mentha (Lamiaceae). Taxon 29: 233-255.

Tucker, A.O. and Naczi, R.F.C. 2007. Mentha: An overview of its classification and relationships. In: Lawrence, B.M. (Ed.), Mint: the genus Mentha. CRC Press, London, pp. 3-4.

(Manuscript received on 23 February 2012; revised on 4 November 2012) 